\title{
Synchronous and metachronous
} malignant melanomas arising in a human immunodeficiency virus-positive patient after the commencement of highly active antiretroviral therapy treatment: a case report

\author{
Sharad P. Paul ${ }^{1 *}\left(\mathbb{0}\right.$, Simon Briggs ${ }^{2}$ and Michael Hitchcock ${ }^{2}$
}

\begin{abstract}
Background: We present an unusual case of a patient who developed four melanomas within a few months of diagnosis with human immunodeficiency virus and commencement of highly active antiretroviral therapy therapy. The patient had no previous history of melanoma, and previous skin checks were normal.

Case presentation: A 50-year-old Caucasian male drainlayer with Fitzpatrick type 2 skin presented for a routine skin examination. He had been diagnosed with human immunodeficiency virus 4 months earlier and commenced on highly active antiretroviral therapy therapy. He was found to have three melanomas (melanoma in situ stage) on excision biopsies, and when he presented for wider excisions of these sites a few weeks later, another new melanoma in situ was found. He had no other medical history of note, and no symptoms to report. He is being followed up 3-monthly.

Conclusions: This case of a human immunodeficiency virus-positive person presenting with four cutaneous melanomas-occurring in both synchronous and metachronous fashion within a 4-month period -is being presented both for its uniqueness and also to highlight the increased need for close skin surveillance in human immunodeficiency virus-positive patients.
\end{abstract}

Keywords: Melanoma, HIV, Antiretroviral drugs, Skin cancer

\section{Introduction}

Human immunodeficiency virus (HIV) infection has been associated with skin manifestations of cancers such as Kaposi's sarcoma and non-Hodgkin's lymphoma. Even in the post-highly active antiretroviral therapy (HAART) era, the risk of melanoma in those with HIV/acquired immunodeficiency syndrome (AIDS) remains elevated.

\footnotetext{
*Correspondence: doctor@skinsurgeryclinic.co.nz

${ }^{1}$ Faculty of Surgery, University of Auckland, Auckland, New Zealand

Full list of author information is available at the end of the article
}

We present an unusual case of a patient who developed four melanomas within a few months of diagnosis of HIV and commencement of HAART therapy.

\section{Case presentation}

Demographic details: 50-year-old Caucasian male drainlayer with Fitzpatrick type 2 skin

Medical history: Recent diagnosis of HIV (4 months ago) and commencement of HAART therapy (2 months ago). No other medical conditions.

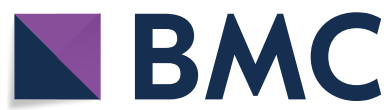

(c) The Author(s) 2021. Open Access This article is licensed under a Creative Commons Attribution 4.0 International License, which permits use, sharing, adaptation, distribution and reproduction in any medium or format, as long as you give appropriate credit to the original author(s) and the source, provide a link to the Creative Commons licence, and indicate if changes were made. The images or other third party material in this article are included in the article's Creative Commons licence, unless indicated otherwise in a credit line to the material. If material is not included in the article's Creative Commons licence and your intended use is not permitted by statutory regulation or exceeds the permitted use, you will need to obtain permission directly from the copyright holder. To view a copy of this licence, visit http://creativecommons.org/licenses/by/4.0/. The Creative Commons Public Domain Dedication waiver (http://creativeco mmons.org/publicdomain/zero/1.0/) applies to the data made available in this article, unless otherwise stated in a credit line to the data. 
Symptoms and signs: Nil. Patient was not aware of any skin issues and presented for a routine skin examination given his outdoor occupation. Three pigmented lesions suspicious for melanoma were identified on his trunk, which turned out to be melanoma in situ (MIS).

Treatment or intervention and outcomes: following wide excision of the MIS sites, the patient is well and is being followed up 3-monthly with skin examinations. Another MIS and a nodular basal cell carcinoma (BCC) have since been diagnosed, and excised.

\section{Clinical history}

As summarized above, a 50-year-old Caucasian male drainlayer presented for a routine skin examination given his outdoor occupation and the approaching summer season. Of note, he had been diagnosed with HIV 4 months earlier, and commenced on HAART therapy with dolutegravir, emtricitabine, and tenofovir 2 months prior to this skin examination. He had no other medical conditions or symptoms, and his past history was unremarkable. He was continuing to work actively as a drainlayer and was not aware of any suspicious lesions on his skin. He had Fitzpatrick type 2 skin, but no previous history of skin cancer. Three small $2-3 \mathrm{~mm}$ pigmented lesions on his trunk were suspicious for melanoma (left shoulder, lower back, and right shoulder) and excision biopsies were performed on these lesions. Histology confirmed these lesions to be melanoma in situ (MIS), and the patient was booked for wider excisions to ensure 5-mm margins in keeping with melanoma guidelines.

During these wider excisions, which were done approximately 8 weeks after his initial excisions, a new pigmented lesion on his right scapular region had appeared, which also appeared atypical on dermatoscopy; this lesion turned out to be another MIS-his fourth in 4 months. Dermatoscopy of these MIS lesions, given their very recent, sudden onset and small size-around $2 \mathrm{~mm}$-showed mainly irregular hyperpigmented areas (Fig. 1).

This case of a HIV-positive person presenting with four cutaneous melanomas-occurring in both synchronous and metachronous fashion within a 4-month period-is being presented both for its uniqueness and to highlight the increased need for close skin surveillance in HIVpositive patients.

\section{Investigations}

At the time of his HIV diagnosis, his CD4 count was 83 cells $/ \mu \mathrm{L}$ (5\%). This is a low CD4 count (anything below 200 is considered low).

Histopathology examination of the initial excision biopsies was typical for melanoma in situ, with nests of malignant melanocytes that varied markedly in size. There were no distinctive features to suggest infection by human immunodeficiency virus. Patients with HIV
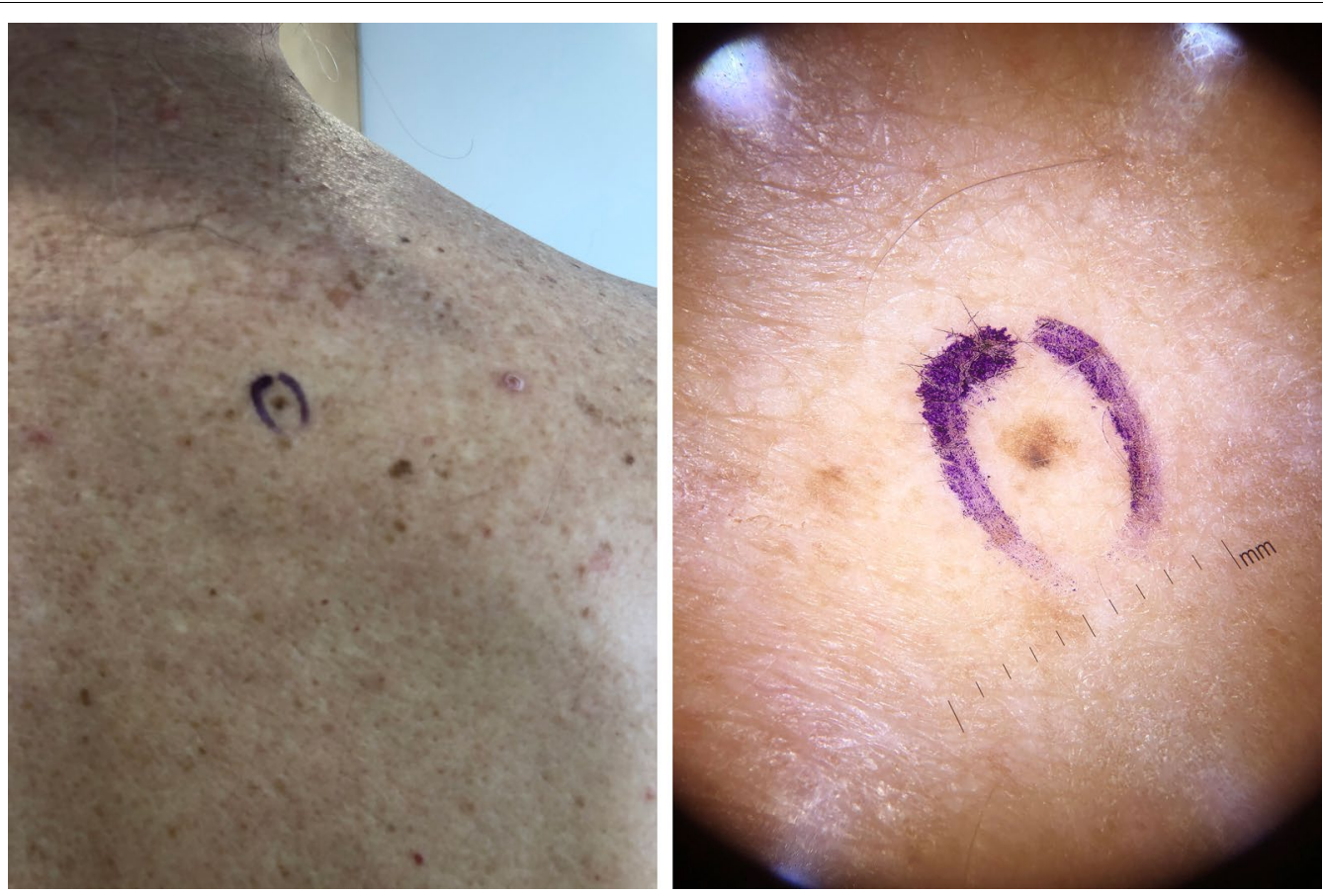

Fig. 1 Clinical and dermatoscopic photographs of the pigmented lesion (MIS) noted on the right scapular region 

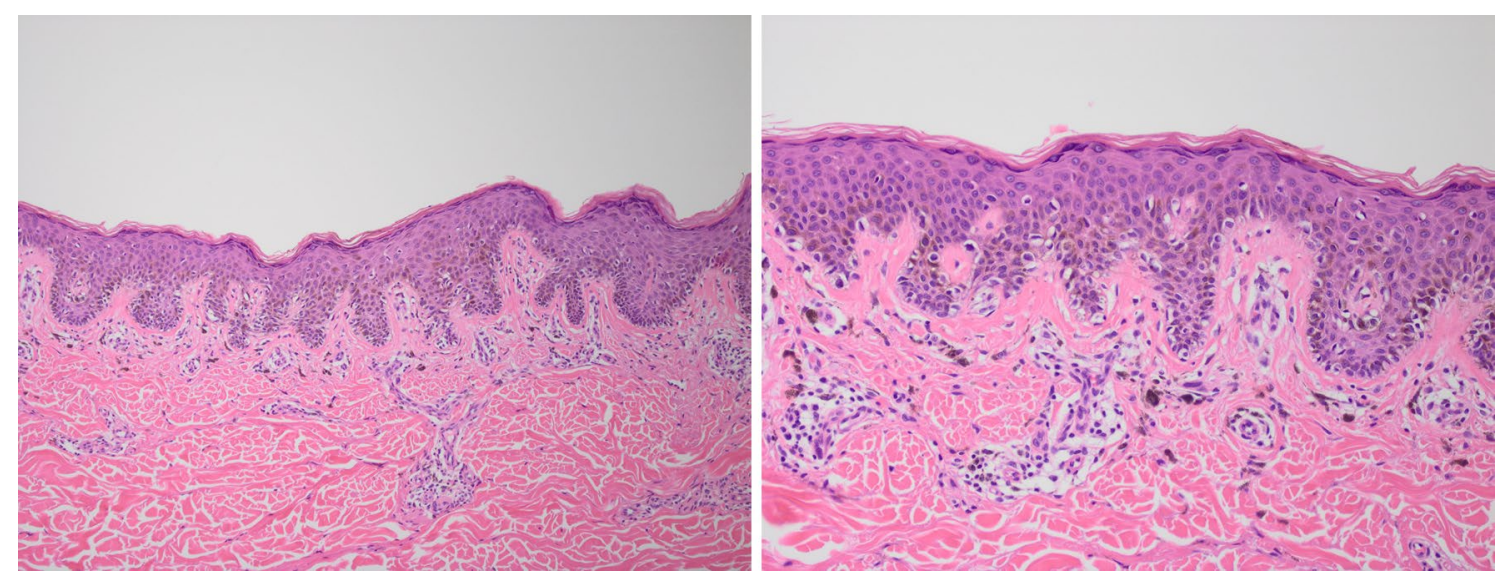

Fig. 2 Magnification images, $4 x$ and 10x, of lower back lesion showing markedly increased single and hyperchromatic melanocytes distributed along the base of the epidermis. There is focal upward extension into the epidermis. The pigmented cells seen in the dermis are melanophages

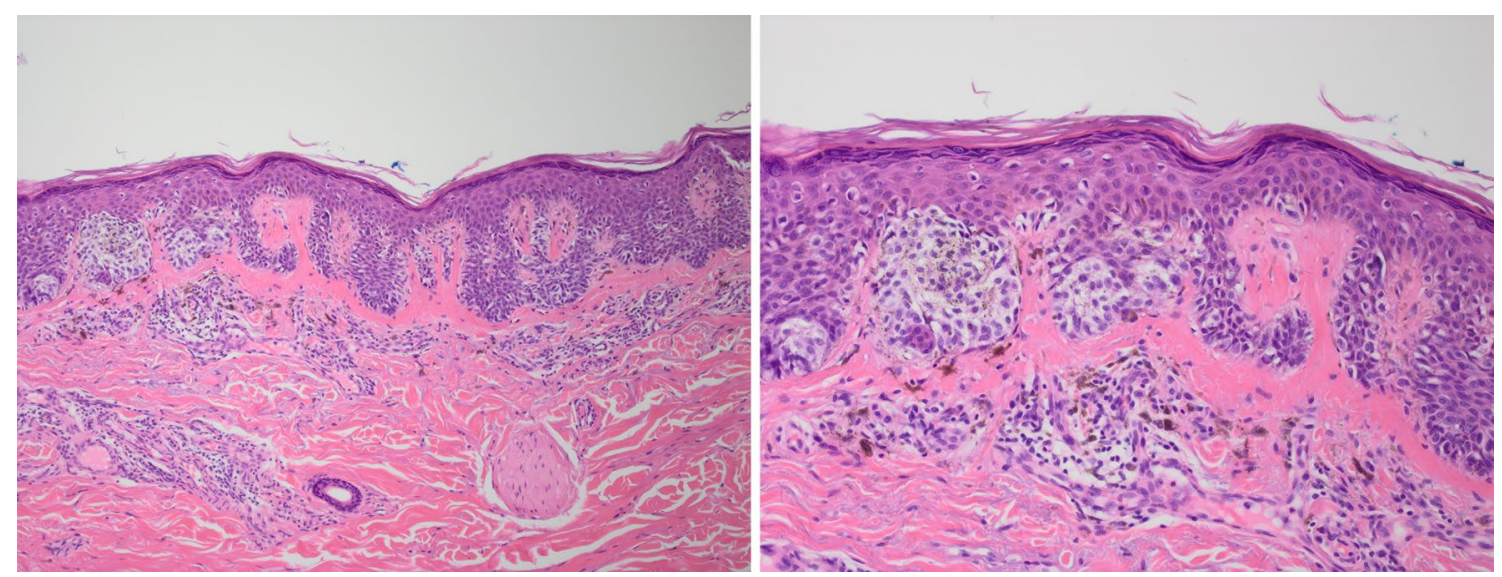

Fig $310 x$ and $20 \times$ magnification images of the right shoulder lesion. The nests of malignant melanocytes vary markedly in size. Melanocytes are extending up into the epidermis. There is a lymphocytic infiltrate in the dermis, but no invasion

sometimes show an excess of eosinophils in their inflammatory reaction, but this was not present in this case (Figs. 2, 3).

\section{Treatment and outcome}

Surgical management (after the initial excisional biopsies) was wide excision of the primary tumor sites to ensure minimum $5 \mathrm{~mm}$ margins all around, in keeping with clinical guidelines for the management of malignant melanoma. Informed consent was obtained for the procedures, as well as for publication of his images and history in medical journals.

Following excision of the MIS lesions, the patient is well. He is doing well on the HAART therapy and is being followed up 3-monthly for skin checks.
During the 3-monthly full body skin examinations another basal cell carcinoma has since been detected and excised from his trunk. As he is currently 9 months following his HIV diagnosis, we do not have longer-term data. The clinical history timeline is outlined in Fig 4. It is noteworthy that in previous skin examinations prior to his HIV diagnosis, including 2 years previously, he had no suspicious lesions. He also had no previous history of melanoma. He is currently well, asymptomatic both from the point of view of his skin and HIV infection and is being followed up by both skin cancer and infectious disease teams. 


\section{Timeline of Medical History}

\section{Synchronous and Metachronous Malignant Melanomas arising in a HIV-positive patient after the} commencement of HAART Treatment: A Case Report

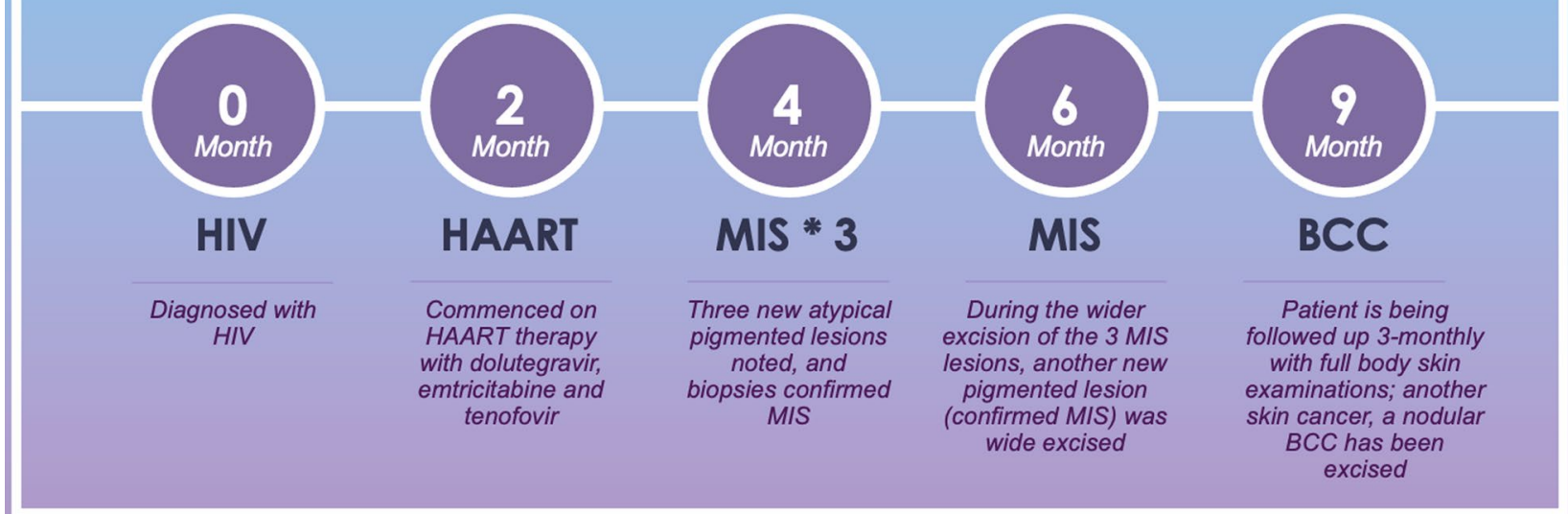

Fig. 4 Clinical history timeline

\section{Discussion}

A study of the incidence of cutaneous melanoma in HIV-positive patients prior to the introduction of highly active antiretroviral therapy (HAART) in the late 1990s reported an overall standardized incidence ratio for melanoma of 1.24 (95\% CI 1.04-1.48) [1]. Pre- and postHAART studies have not shown any differences in the incidence of melanoma but confirm that people with HIV/AIDS have a $50 \%$ increased risk of developing a cutaneous melanoma [2].

Over $70 \%$ of primary melanoma patients develop their second melanoma within 5 years of the first malignancy, and over $90 \%$ develop their second melanoma within 10 years after the first [3]. While patients with multiple primary invasive melanomas are at increased risk of death compared with patients with single primary invasive melanomas, it is interesting that for patients with melanoma in situ (MIS), those with multiple lesions appear to have better outcomes when compared with patients with a single MIS [3]. We are aware of one study that studied the risk of melanoma among individuals infected with HIV by considering only recent CD4 counts that reported elevated relative risks for individuals with CD4 counts under 200 and 201-499 cells/ $\mu \mathrm{L}$, but not for those with CD4 counts greater than 500 cells $/ \mu \mathrm{L}$ [4]. A study noted that when compared with uninfected individuals, those with HIV infection and CD4 count $<200$ cells $/ \mu \mathrm{L}$ had a $44 \%$ increased risk of subsequent non-melanoma skin cancer (NMSC) overall and a $222 \%$ increase risk of squamous cell carcinoma (SCC) in particular, suggesting that subsequent SCC risk is associated with immune dysfunction, but melanoma was not mentioned similarly [5].

There is a dearth in the literature of evidence regarding the prognosis for patients with multiple primary melanomas compared with those with single primary melanomas [3], and even less in the context of HIV-positive patients. A recent study suggested that overall survival was worse among patients with multiple primary melanomas compared with patients with a single primary melanoma [6]. However, other studies show that, for melanomas in general, prognosis for multiple MIS may indeed be better than for patients with single MIS, and many factors account for this decreased effect size [7, 7].

Longevity for patients with HIV is rising with the advent of HAART [9]. The worldwide incidence of melanoma has also been rising in most fair-skinned populations [10]. Because HAART has turned HIV infection into a chronic disease, patients with advancing age are at a higher risk of cardiovascular, renal, neurological, and, indeed, skin diseases [11]. Therefore, for people living with HIV, immunodeficiency leads to a higher risk of developing malignancies, and is further amplified by risk factors for development of different cancers. In other words, occupational or recreational sun exposure increases the risk of skin cancer even further [12]. 
Interestingly, there has been a decrease in the incidence of AIDS-defining cancers such as Kaposi's sarcoma and non-Hodgkin lymphoma, but increases in incidence of many non-AIDS-defining cancers such as skin cancer [13].

Organ transplant recipients treated with immunosuppressive drugs are known to have a higher risk of melanoma, indicating that immunosuppression can trigger melanoma skin cancer [1]. The association between HIV and melanoma is also important to understand better, not only because of the role for immunosuppression in melanoma genesis, but also for the fact that immune checkpoint inhibitors are becoming the mainstay in managing advanced melanoma [14]. We know that tumorassociated antigens are expressed by melanoma cells [15], and most doctors dealing with melanoma would have clinically observed spontaneous tumor regression in some patients with primary melanoma, suggesting some degree of immune modulation [16]. Immunosuppressive drugs also keep organ transplant patients alive for longer, and researchers note that transplant recipients are four times more likely to be diagnosed with regional stage melanoma, that is, melanoma that has already begun to spread to other parts of the body [17]. This finding rules out the possibility that increased skin surveillance of transplant patients is the cause of this increased incidence or diagnosis of melanoma [17].

Melanoma rates are rising globally. New Zealand and Australia-with fair-skinned populations living in environments with high ultraviolet (UV) radiation-have the greatest burden, with disability-adjusted life years scores of 54 [18]. According to the US cancer data supplied by the CDC, from 2013-2017 there were 406,132 new cases of cutaneous melanomas reported, and 43,847 people died of melanomas of the skin, with an overall incidence rate of just under 22 per 100,000 people [19]. CDC figures for HIV infections show that, in 2018, the HIV incidence remained similar to the rate in 2014, with no rise in infection rates. However, while the rate is twothirds lower than the peak in the 1980s, the rate of new HIV infections has not reduced significantly since 2014 [20]. The estimated number of HIV infections in 2018 was 36,400 , and the incidence rate was just over 13 per 100,000 people [20].

The melanoma rate is higher than the rate of HIV infections in countries with fair-skinned populations. However, because melanin is an antioxidant, the degree of immune response (or lack of) that results in a malignant melanoma is worsened by immunosuppression due to drugs (such as used after transplants) or diseases (such as HIV).

\section{Conclusion}

The case presented in this report is unusual because of the rapid development of multiple melanomas over a short period of time in a HIV-positive patient after diagnosis and commencement of treatment. Another reason for this case report is because HIV is not mentioned specifically in melanoma guidelines of care. Fair-skinned people with HIV/AIDS would benefit from close surveillance of their skin for suspicious pigmented lesions because their melanoma rate is increased by 50\% [2]. These patients also have a significant, at least twofold, increased risk of developing keratinocyte skin cancers [21] such as basal and squamous cell carcinomas, and therefore should be counseled regarding sun exposure, UV damage, and sun protection.

\section{Takeaway lessons}

- This is an interesting case with multiple melanomas, synchronous and metachronous, developing rapidly in an HIV-positive patient

- While immunosuppression associated with transplant treatment is often associated with higher skin cancer risk, HIV is often overlooked in this regard

- HIV-positive patients with fair skin have a 50\% increased rate of developing melanoma and must undergo regular skin surveillance

\section{Patient perspective}

"A few years ago, I had a weird looking mole on my back so went to get a mole check. It was benign. I was not aware that I had any increased risk after my diagnosis as no one told me. I have had mole checks in the past ... being a drainlayer and working outside. This time I had myself decided it was time to get my skin checked"

\footnotetext{
Abbreviations

HAART: Highly active antiretroviral therapy; MIS: Melanoma in situ; CDC: Centers for Disease Control and Prevention; BCC: Basal cell carcinoma; SCC: Squamous cell carcinoma.
}

\section{Acknowledgements}

No acknowledgements to report, other than authorship. Individual author contributions are already mentioned earlier, and all authors give permission for the publication of this article.

\section{Authors' contributions}

SPP wrote the manuscript and was involved in surgical management and patient care. SB was involved in patient care and HIV management, and $\mathrm{MH}$ was histopathologist. SB and $\mathrm{MH}$ helped edit the manuscript, and $\mathrm{MH}$ 
provided the histopathology slides. All authors read and approved the final manuscript.

\section{Funding}

No funding sources to report.

\section{Availability of data and materials}

Not applicable.

\section{Declarations}

Ethics approval and consent to participate

Not applicable

\section{Consent for publication}

Written informed consent was obtained from the patient for publication of this case report and any accompanying images. A copy of the written consent is available for review by the Editor-in-Chief of this journal.

\section{Competing interests}

None.

\section{Author details}

${ }^{1}$ Faculty of Surgery, University of Auckland, Auckland, New Zealand. ${ }^{2}$ Auckland District Health Board, Auckland, New Zealand.

Received: 5 May 2021 Accepted: 20 May 2021

Published online: 14 July 2021

\section{References}

1. Grulich AE, van Leeuwen MT, Falster MO, Vajdic CM. Incidence of cancers in people with HIV/AIDS compared with immunosuppressed transplant recipients: a meta-analysis. Lancet. 2007;370:59-67.

2. Olsen CM, Knight LL, Green AC. Risk of melanoma in people with HIV/ AIDS in the pre- and post-HAART eras: a systematic review and metaanalysis of cohort studies. PLOS ONE. 2014;9(4):e95096.

3. Nosrati A, Yu WY, McGuire J, et al. Outcomes and risk factors in patients with multiple primary melanomas. J Invest Dermatol. 2019;139(1):195-201.

4. Silverberg MJ, Chao C, Leyden WA, Xu L, Horberg MA, et al. HIV infection, immunodeficiency, viral replication, and the risk of cancer. Cancer Epidemiol Biomarkers Prev. 2011;20:2551-9.

5. Asgari MM, Ray GT, Quesenberry CP Jr, Katz KA, Silverberg MJ. Association of multiple primary skin cancers with human immunodeficiency virus infection, CD4 count, and viral load. JAMA Dermatol. 2017;153(9):892-6.

6. El Sharouni M, Witkamp AJ, Sigurdsson V, van Diest PJ. Comparison of survival between patients with single vs multiple primary cutaneous melanomas. JAMA Dermatol. 2019;155(9):1049-56.
7. Pardo LM, van der Leest RJT, de Vries E, Soerjomataram I, Nijsten T, Hollestein LM. Comparing survival of patients with single or multiple primary melanoma in the Netherlands: 1994-2009. Br J Dermatol. 2016;176:531-3.

8. Youlden DR, Baade PD, Soyer HP, Youl PH, Kimlin MG, Aitken JF, et al. Ten-year survival after multiple invasive melanomas is worse than after a single melanoma: a population-based study. J Invest Dermatol. 2016;136:2270-6.

9. Palella FJ Jr, Delaney KM, Moorman AC, Loveless MO, Fuhrer J, et al. Declining morbidity and mortality among patients with advanced human immunodeficiency virus infection. HIV Outpatient Study Investigators. N Engl J Med. 1998;338:853-60.

10. Ferlay J, Steliarova-Foucher E, Lortet-Tieulent J, Rosso S, Coebergh JW, et al. Cancer incidence and mortality patterns in Europe: estimates for 40 countries in 2012. Eur J Cancer. 2013;49:1374-403.

11. Ceccarelli M, VenanziRullo E, Vaccaro M, et al. HIV-associated psoriasis: epidemiology, pathogenesis, and management. Dermatol Ther. 2019;75(10):e12806-e12806.

12. Crum-Cianflone $\mathrm{N}$, Hullsiek KH, Satter $\mathrm{E}$, et al. Cutaneous malignancies among HIV-infected persons. Arch Intern Med. 2009;169(12):1130-8.

13. Long JL, Engels EA, Moore RD, Gebo KA. Incidence and outcomes of malignancy in the HAART era in an urban cohort of HIV-infected individuals. AIDS. 2008;22:489-96.

14. Cebon J, Gedye C, John T, Davis ID. Immunotherapy of advanced or metastatic melanoma. Clin Adv Hematol Oncol. 2007;5:994-1006.

15. Houghton AN, Gold JS, Blachere NE. Immunity against cancer: lessons learned from melanoma. Curr Opin Immunol. 2001;13:134-40.

16. Kalialis LV, Drzewiecki KT, Klyver H. Spontaneous regression of metastases from melanoma: review of the literature. Melanoma Res. 2009;19:275-82.

17. Robbins HA, Clarke CA, Arron ST, et al. Melanoma risk and survival among organ transplant recipients. J Invest Dermatol. 2015;135(11):2657-65.

18. Karimkhani C, Green AC, Nijsten T, et al. The global burden of melanoma: results from the Global Burden of Disease Study 2015. Br J Dermatol. 2017;177(1):134-40.

19. U.S. Cancer Statistics Working Group. U.S. Cancer Statistics Data Visualizations Tool, based on 2019 submission data (1999-2017): U.S. Department of Health and Human Services, Centers for Disease Control and Prevention and National Cancer Institute; www.cdc.gov/cancer/dataviz, released in June 2020

20. Centers for Disease Control and Prevention. Estimated HIV incidence and prevalence in the United States, 2014-2018. HIV Surveillance Supplemental Report 2020;25(No. 1). http://www.cdc.gov/hiv/library/reports/ hiv-surveillance.html. Published May 2020. Accessed 20 July 2020.

21. Silverberg MJ, Leyden W, Warton EM, Quesenberry CP Jr, Engels EA, et al. HIV infection status, immunodeficiency, and the incidence of nonmelanoma skin cancer. J Natl Cancer Inst. 2013;105:350-60.

\section{Publisher's Note}

Springer Nature remains neutral with regard to jurisdictional claims in published maps and institutional affiliations.
Ready to submit your research? Choose BMC and benefit from:

- fast, convenient online submission

- thorough peer review by experienced researchers in your field

- rapid publication on acceptance

- support for research data, including large and complex data types

- gold Open Access which fosters wider collaboration and increased citations

- maximum visibility for your research: over 100M website views per year

At BMC, research is always in progress.

Learn more biomedcentral.com/submissions 